\title{
Preservation of sweet red pepper paste quality: effect of packing material, ozone gas and protective agent use
}

\author{
Ruhan AȘKIN UZEL ${ }^{1 *}$
}

\begin{abstract}
Unlike conventional methods, sweet red pepper paste was produced by various techniques in assistance of various starter cultures. Products were stored at $37^{\circ} \mathrm{C}$ for 60 days. Salinity, acidity, color change, invert sugar, brown pigment formation parameters were determined during storage period. Microbiological, statistical and sensory evaluation methods were also applied and the effects of Polyethylene Terephthalate (PET) and Polypropylene (PP) at different filling temperatures with and without protective agents were investigated. E. coli was not detected at any production stage. Samples treated with protective agents at higher temperature was found to be best with respect to panelists' flavor and color quality scores in PP support as a result of deterioration has occurred in samples with PET material. The results provide a basis for increasing active components and functional activity in pepper paste production by controlling packing material and ozone gas release considering chemical and sensory properties.
\end{abstract}

Keywords: ozone treatment; parameter; pepper paste; polyethylene terephthalate (PET); polypropylene (PP).

Practical Application: Effective preservation of pepper paste quality using green materials and effective conditions.

\section{Introduction}

As a member of the Capsicum family, sweet red pepper (Capsicum annum L.) can be cultivated in many ways and different forms of consumption are available. It is used as a spice to medicine, as well as being a natural colorant in many kinds of food. Being an alternative, red pepper is highly consumed in the home- or factory-made paste form (Kim et al., 2016; Hanif et al., 2016; Kilic et al., 2011; Semenli \& Mavi, 2010; Srinivasan, 2016; Wang et al., 2017; Duman et al., 2002; Erkmen, 2010; Gül et al., 2005). Furthermore, the production of pepper paste disinfection-by-products such as chlorinated organic compounds (e.g. trihalomethanes) which are potential carcinogens has created the need to investigate the efficacy of non-traditional sanitizers and other alternative technologies such as ozone (Tzortzakis \& Chrysargyris, 2017; Fawell, 2000).

Studies on the quality of red pepper paste have been examined and it was seen that different production methods and process parameters changed some properties of red pepper paste (Riquelme \& Matiacevich, 2017). Also, the effect of pungent flavor component called capsaicin by means of distortion causing microorganisms was studied and it was finally observed that all bitterness components could stop the development of microorganisms (Hanif et al., 2016; Kim et al., 2017a, b; Lim et al., 2001; Li et al., 2016; Sanyaolu, 2016). The number of literature examples for pepper paste production could be increased. However, there is lack of information about sensory and characteristic properties of sweet red pepper paste considering its chemical and microbiological properties in proper packing material. Therefore, the aim of this study was to determine the quality characteristics of red pepper paste considering combined effects of production parameters during storage of pepper paste produced in the presence and absence of ozone gas at different filling temperatures for different packaging materials such as PET and PP, respectively.

\section{Materials and methods}

In current study, raw material of sweet red peppers (Capsicum annum L.) were grown in various locations of the Aegean Region (Turkey) and have been supplied by local manufacturers. Sodium benzoate, potassium sorbate, phenolphthalein and $\mathrm{NaCl}$ were obtained from Merck (Darmstadt, Germany).

\subsection{Sweet red pepper paste production}

Sweet red pepper paste used in the study was manufactured in the plant located in Izmir, Turkey. Seed and stems of peppers were firstly separated and then washed thoroughly with three times the weight of mass of water in the same day after raw material supply. After mincing in a shredder to nearly $80 \mathrm{~mm}$ particle size (Nanyang Wanxin Food Machinery Co., Ltd, China), whole material was steamed at $110 \pm 1{ }^{\circ} \mathrm{C}$ for $5,8,11$ minutes and boiled for 25 minutes in water until they were completely tendered. Boiled peppers were palpated to obtain pulp and pepper paste via vaporization. The production steps were summarized in Figure 1 (Kuleaşan \& Okur, 2012). 


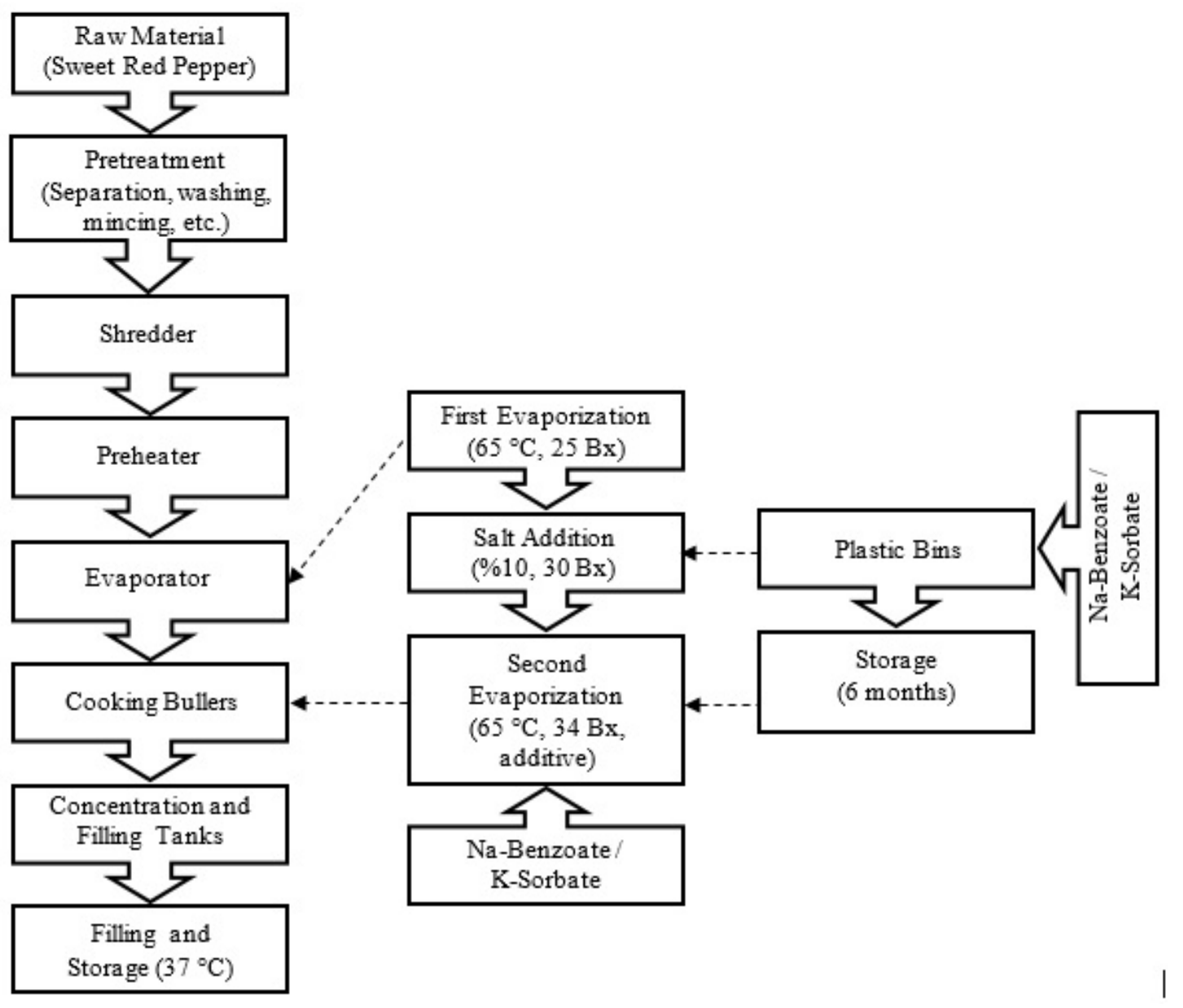

Figure 1. Sweet red pepper paste production steps.

Final product which is in pulp form was taken into two separate tanks. $0.2 \%$ concentrated protective agent (equal proportions of Na-Benzoate and K-Sorbate) was added by dosing pumps while any preventative was not added to the other pulp in the second tank (Figure 2).

The same procedure (heating, cooling, evaporation, etc.) was applied to both pulps in the tanks and filling process took place at three different temperatures of 50,60 and $85^{\circ} \mathrm{C}$, respectively. Samples were heated for $25 \mathrm{~min}$ and cooled for $45 \mathrm{~min}$ each. PET (Polyethylene Terephthalate) and PP (Polypropylene) packaging materials were used separately for each temperature value. PET and PP packaging materials were used separately for each temperature value used in the process. Twenty samples were prepared for each type of production method. All of the samples were divided in two and some were treated with ozone gas for disinfection while ozone was not used for the other part. Twelve samples were exposed to ozone concentration of $35 \mathrm{mg} / \mathrm{m}^{3}$ for $2 \mathrm{~h}$ per day, at controlled temperature of 50,60 and $85^{\circ} \mathrm{C}$ in presence and absence of protective agents. Products were stored in an incubator (NUVE, EN 500, Ankara, Turkey) at $37^{\circ} \mathrm{C}$ for 60 days. Triple samples were prepared for each technique. Quality parameters such as $\mathrm{pH}$, salinity, acidity, etc. were evaluated by applying microbiological, statistical and sensory measurements at storage period. Triple samples were prepared for each analysis. So, seventy two samples were prepared for each production method.

\subsection{Microbiological counts}

Samples of $30 \mathrm{~g}$ each were taken from each tank and homogenized in a sterile Waring 8011 EB Blender (Altan Endustriyel ve Laboratuvar Cih. A.Ş., Turkey) containing $270 \mathrm{~mL}$ $0.1 \%$ peptone water. They were diluted serially using $0.1 \%$ peptone (Sigma-Aldrich Chemie GmbH, Taufkirchen, Germany). Aerobic Plate count (APC) and with mold-yeast count were done using aerobic Plate Count Agar (PCA) (Sigma-Aldrich, Germany) and Potato Dextrose Agar (PDA) (Sigma-Aldrich, Germany), respectively. For E. coli count, sample material was diluted with sterile phosphate buffer until the bacteria was dilute enough to count accurately. Samples were incubated at $35-37{ }^{\circ} \mathrm{C}$ for 24-48 hours and at $25-28^{\circ} \mathrm{C}$ for 5 days in case of aerobic plate count and mold-yeast count, respectively.

\subsection{Chemical analysis}

Samples were analyzed for determination of acidity, $\mathrm{pH}$, brown pigment formation, invert sugar values. Most of analytical features of sweet red pepper paste were determined by following Association of Official Agricultural Chemists (1995) methods 


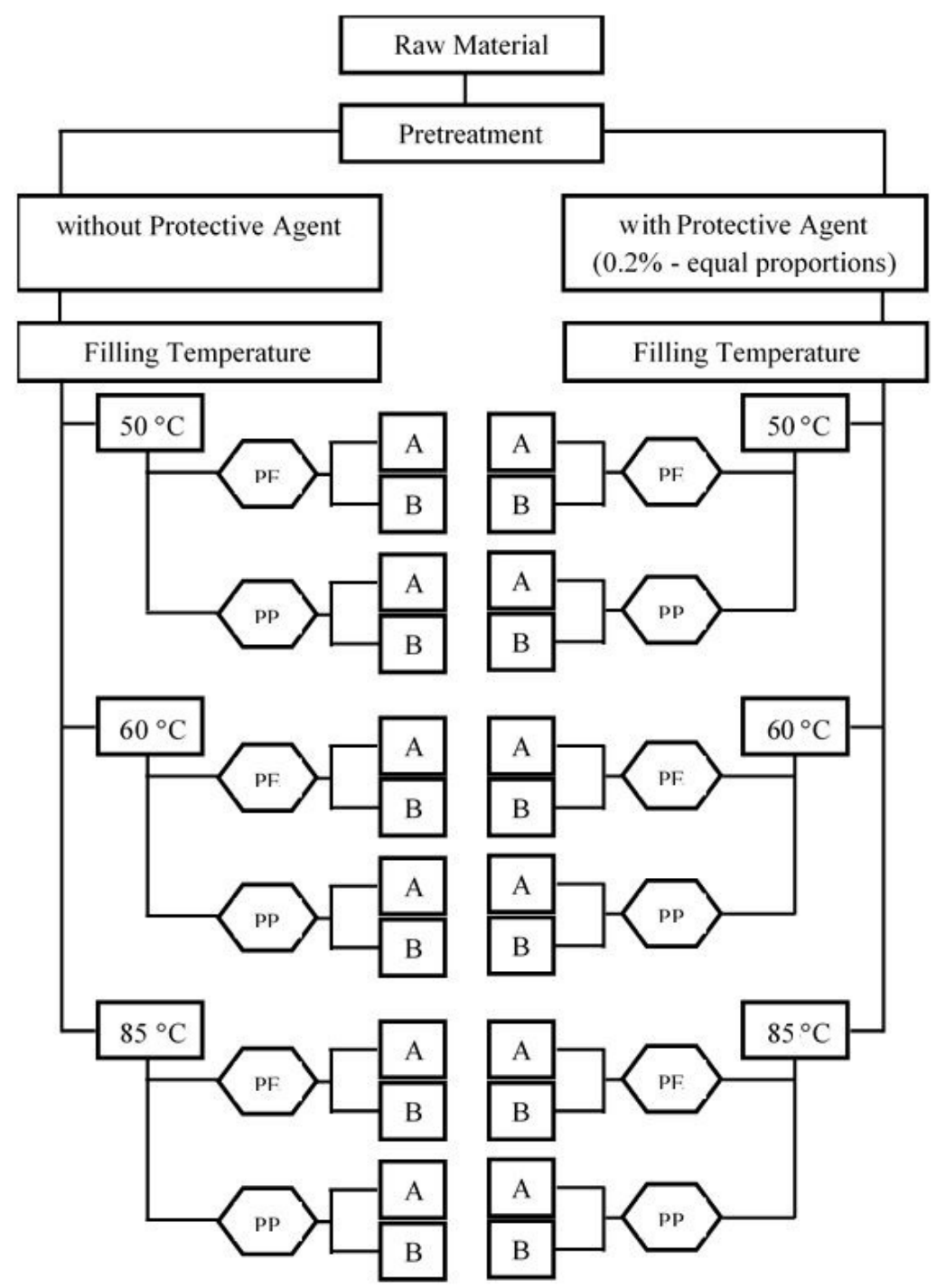

Figure 2. Process conditions for pepper paste production (A: with ozone; B: without ozone).

(Stamp \& Labuza, 2006) and Turkish Standards Institution (TSI) regulations. TSI determines total acidity for pepper paste in terms of citric acid). Also, literature has expressed the approximate $\mathrm{pH}$ range for sweet red pepper paste between 3.5 and 4.7 (Nath et al., 2016; Cho et al., 2016). Brown pigment formation was determined in terms of optical density at $420 \mathrm{~nm}$ absorbance level using a Beckman DB-G spectrophotometer (Beckman Instruments Inc., USA). Sugar content in the products was expressed as invert sugar and the reducing sugar level was specified following Lane-Eynon general volumetric method (Association of Official Analytical Chemistry, 1995; Göğüş et al., 2016).

\subsection{Sensory analysis}

Products were evaluated in terms of sensory properties. As important as chemical and microbiological analysis, it is important to know about sensory parameters and properties of pepper paste by the panelists. For this reason, sensory analysis was applied not only for product development, but also for adjustment of process parameters and application of new methods for production and / or packaging. Within the scope of this research, preparation and evaluation of sensory characteristics of red pepper paste samples were aimed by characterization and assessment of chemical and microbiological behavior for different temperatures for In face of that, this research aimed to prepare and to evaluate the sensory characteristics of a tucupi creamy paste, as well as to characterize and assess its rheological behavior at packing material, ozone gas and protective agent use at different temperatures.

The sensory analysis was carried out in a standard sensory laboratory provided with 6 testing booths. For the analysis, a group of 6 people ( 3 women and 3 men) was selected among trained panelists. The panelists have been practicing for six months to form sensory profiles after being educated. $25 \mathrm{~mL}$ of samples were presented to the panelists in white porcelain cups with rounded edges. Samples were given to panelists one by one, preferably and a scale beginning from 1 to 10 was used for each sensory attribution with respect to panelists' 
perceptions. The results that obtained from panelists were evaluated by variance analysis. Color hue, resistance to taking and stirring and ladling with a spoon, resistance to pouring from the spoon, viscosity for ingesting and pressing, overall flavour acceptability, bitter taste after chewing and swallowing were specified as main decriptors.

\subsection{Statistical analysis}

Data on impact of ozone and PET-PP packing material use against filling temperature difference on pepper paste quality in presence and absence of protective agents were analyzed with Duncan's multiple comparison test $(\mathrm{p}<0.05)$ using the SPSS software package, version 13.0 (SPSS Inc., Chicago, IL, USA) (SPSS Inc., 2010). The statistical analyses were conducted using SPSS software (SPSS Inc., version 11.0) by analysis of variance (ANOVA) to establish effects different packaging materials and protective agent addition at relevant filling temperatures the differences in the treatments. $99 \%$ confidence level was taken into consideration. In addition, "Design Expert Ver. 7.0.0" program was used for formation production patterns (Stat-Ease, 2005). This program revealed a scientific manner about mixing orders of each protective agent, mixing proportions and the number of parallel productions.

\section{Results and discussion}

\subsection{Microbiological assessment}

Microbiological analysis showed that $E$. coli was not detected in raw material and in the final product at any production stage.

However, it is noteworthy that mold and yeast development started from the beginning of the second storage period and continued at following periods for both samples with and without protective agents in PET packing material use and in PP packing material use (Table 1 and Table 2).

Statistical analysis indicated that all the two-way interactions for each packaging material in presence and absence of ozone (time $\times$ temperature, time $\mathrm{x}$ protective agent, and protective agent $\times$ temperature) were significant $(P<0.05)$. This means that effect of combinations of the factors changed the total microbial count more than the effect of one factor. This showed necessity of protective agent use in proper sweet red pepper paste production stages comparing to ozone usage.

\subsection{Chemical changes}

Due to the inherent differences in raw materials used for the production of red pepper paste $\mathrm{pH}$ values changed in the range from 5.38 to 5.42 .

Temperature difference in filling process did not change the $\mathrm{pH}$ value, whereas increase in total sugar content of the final product caused a higher acidity, in other terms a lower $\mathrm{pH}$ value. It was noteworthy that whether PET or PP, the use of different packaging material did not show any positive or negative effect on $\mathrm{pH}$ value. Instead, use of protective agents increased pepper paste acidity (Table 3 ). There was no difference between raw material and processed samples in case of brown pigment formation. This proves that there was no perforation on palper sieves during production and the thermal process did not affect the formation of brown pigments.

\subsection{Physical and sensory quality}

Filling was done at three different temperatures as 50,60 , and $85^{\circ} \mathrm{C}$ for each packaging material. PET based filling at high temperatures such as $85^{\circ} \mathrm{C}$ reduced the capacity for

Table 1. Changes in microbial counts during storage in the sweet red pepper paste prepared by different techniques (cfu/g)* without protective agents (P. A)**.

\begin{tabular}{|c|c|c|c|c|c|c|c|c|c|}
\hline \multirow{2}{*}{ Time (days) } & \multirow{2}{*}{ Temp. $\left({ }^{\circ} \mathrm{C}\right)$} & \multicolumn{2}{|c|}{ Aerobic Plate Count (APC) } & \multicolumn{2}{|c|}{ Mold-Yeast Count } & \multicolumn{2}{|c|}{ Lactic Acid Bacteria Count } & \multicolumn{2}{|c|}{ E. coli Count } \\
\hline & & With PET & With PP & With PET & With PP & With PET & With PP & With PET & With PP \\
\hline \multirow[t]{2}{*}{ Raw Material } & 50 & $3 \times 10^{4}$ & $3 \times 10^{4}$ & $2 \times 10^{3}$ & $2 \times 10^{3}$ & $2 \times 10^{4}$ & $1 \times 10^{4}$ & 0 & 0 \\
\hline & 60 & $3 \times 10^{4}$ & $3 \times 10^{4}$ & $2 \times 10^{3}$ & $2 \times 10^{3}$ & $2 \times 10^{4}$ & $1 \times 10^{4}$ & 0 & 0 \\
\hline \multirow[t]{2}{*}{0} & 50 & 0 & 0 & 0 & 0 & 0 & 0 & 0 & 0 \\
\hline & 60 & 0 & 0 & 0 & 0 & 0 & 0 & 0 & 0 \\
\hline \multirow{2}{*}{15} & 60 & 46.76 & 46.84 & 22.75 & 22.37 & 5.99 & 6.21 & 0 & 0 \\
\hline & 85 & 43.27 & 43.00 & 12.44 & 12.45 & 3.55 & 3.75 & 0 & 0 \\
\hline \multirow[t]{3}{*}{30} & 50 & 47.83 & 47.05 & 36.77 & 37.03 & 14.33 & 14.90 & 0 & 0 \\
\hline & 60 & 67.00 & 67.12 & 33.87 & 33.18 & 12.67 & 12.55 & 0 & 0 \\
\hline & 85 & 42.34 & 42.58 & 10.98 & 11.00 & 10.56 & 10.44 & 0 & 0 \\
\hline \multirow[t]{3}{*}{60} & 50 & 82.26 & 82.00 & 100.69 & 100.54 & 42.67 & 42.80 & 0 & 0 \\
\hline & 60 & 25.88 & 25.26 & 77.33 & 78.90 & 33.55 & 33.58 & 0 & 0 \\
\hline & 85 & 11.00 & 10.97 & 56.76 & 56.13 & 22.10 & 21.57 & 0 & 0 \\
\hline
\end{tabular}

${ }^{*} \mathrm{cfu} / \mathrm{g}$ : colony forming unit per grams of sample; ${ }^{* *}$ P. A.: $0.2 \%$ concentrated protective agent (equal proportions of Na-Benzoate and K-Sorbate). 
Table 2. Changes in microbial counts during storage in the sweet red pepper paste prepared by different techniques (cfu/g)* with protective agents (P. A)**.

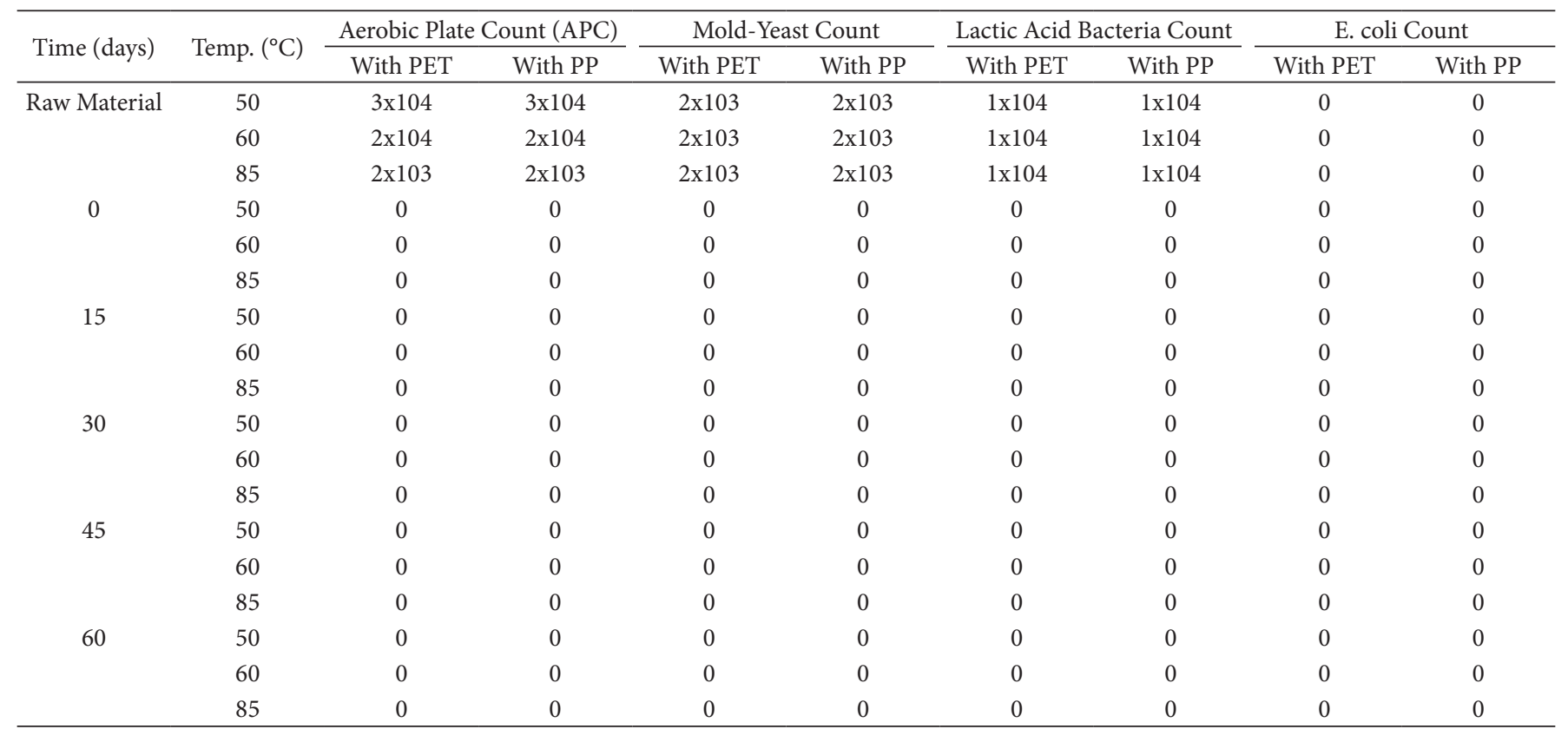

${ }^{*} \mathrm{cfu} / \mathrm{g}$ : colony forming unit per grams of sample; ${ }^{* *}$ P. A.: $0.2 \%$ concentrated protective agent (equal proportions of Na-Benzoate and K-Sorbate).

Table 3. Changes in $\mathrm{pH}$ values, acidity, invert sugar and brown pigment formation during storage in hot pepper paste prepared by different techniques.

\begin{tabular}{|c|c|c|c|c|c|c|c|c|c|}
\hline Time (days) & Temp. $\left({ }^{\circ} \mathrm{C}\right)$ & \multicolumn{2}{|c|}{$\mathrm{pH}$ Values } & \multicolumn{2}{|c|}{ Total Acidity (\%) } & \multicolumn{2}{|c|}{ Invert Sugar (\%) } & \multicolumn{2}{|c|}{$\begin{array}{c}\text { Brown Pigment } \\
\text { (number/grams) }\end{array}$} \\
\hline Raw Material & 50 & 5.42 & 5.38 & 0.25 & 0.36 & 3.00 & 2.5 & 2 & 2 \\
\hline \multirow[t]{2}{*}{0} & 50 & 4.42 & 4.33 & 0.65 & 0.95 & 16.01 & 14.13 & 1 & 1 \\
\hline & 60 & 4.43 & 4.33 & 0.66 & 0.96 & 15.96 & 14.17 & 2 & 2 \\
\hline 15 & 50 & 4.35 & 4.30 & 0.67 & 0.98 & 16.15 & 14.13 & 1 & 2 \\
\hline \multirow[t]{2}{*}{30} & 50 & 4.36 & 4.33 & 0.69 & 0.98 & 16.00 & 14.08 & 1 & 1 \\
\hline & 60 & 4.37 & 4.31 & 0.69 & 0.95 & 15.98 & 14.02 & 2 & 1 \\
\hline \multirow[t]{2}{*}{45} & 50 & 4.41 & 4.31 & 0.68 & 0.96 & 15.93 & 14.12 & 2 & 2 \\
\hline & 60 & 4.44 & 4.32 & 0.68 & 0.97 & 16.05 & 14.05 & 2 & 1 \\
\hline 60 & 50 & 4.35 & 4.32 & 0.68 & 0.97 & 16.05 & 14.17 & 2 & 1 \\
\hline
\end{tabular}

* P. A.: $0.2 \%$ concentrated protective agent (equal proportions of Na-Benzoate and K-Sorbate).

physical endurance and the packing material showed a tendency to slump. Risk of microbiological contamination has been revealed for the products filled at 50 and $60^{\circ} \mathrm{C}$. Thus, inappropriateness of PET packaging at $85^{\circ} \mathrm{C}$ was verified and rapid deformation was incurred. So, it was decided that PET packaging should not be used for elevated temperatures. Whereas, PP packaging material showed temperature-resistant performance at high temperatures. For sensory evaluation, sweet red pepper paste treated with protective agents at higher temperature was found to be best with respect to panelists' flavor and color quality scores. This could be due to acid taste caused by increase in total sugar content of the final product. Total sugar increase was a result of concentration and decomposition of sucrose to glucose and fructose by the effect of thermal processes. However, flavor scores of pepper paste produced without protective agents were not good because of low acid taste and of color unacceptability. During production of pastes without protective agents, the color became darker as a consequence of the brown pigment formation and resulted in low acceptability of color scores by panelists.

\section{Conclusion}

Various production methods were investigated in combination with quality parameters for sweet red pepper paste production in the presence and absence of protective agents at different filling temperatures. Microbial, chemical, and physical and 
sensory qualities of paste were examined in red pepper paste produced by various production techniques at different filling temperatures with and without protective agents. Results showed that effect of combinations of the factors changed the total microbial count more than the effect of one factor. This showed necessity of protective agent use in proper sweet red pepper paste production stages in assistance of ozone gas. To conclude, it has been found that the process parameters investigated in the study can reach a sufficient level in terms of quality, safety and acceptability of the product by manipulating the variables in appropriate combination.

\section{References}

Association of Official Analytical Chemistry - AOAC. (1995). AOAC 923.09.25: invert sugar in sugars and syrups: Lane-Eynon general volumetric method final action: official method of analysis (16th ed., pp. 8-9). Arlington: AOAC.

Cho, W., Yi, J. Y., \& Chung, M. S. (2016). Pasteurization of fermented red pepper paste by ohmic heating. Innovative Food Science \& Emerging Technologies, 34, 180-186. http://dx.doi.org/10.1016/j. ifset.2016.01.015.

Duman, A. D., Zorlugenç, B., \& Evliya, B. (2002). Kahramanmaraş'ta Kırmızı Biberin Önemi ve Sorunları. Kahramanmaraş Sütçü İmam Üniversitesi Doğa Bilimleri Dergisi, 5, 111-114.

Erkmen, O. (2010). Basic methods for the microbiological analysis of foods. New York: Nobel Publishing Company.

Fawell, J. (2000). Risk assessment case study-chloroform and related substances. Food and Chemical Toxicology, 23(1, Suppl), 91-95. PMid:10717377. http://dx.doi.org/10.1016/S0278-6915(99)00129-5.

Göğüş, F., Ötleş, S., Erdoğdu, F., \& Özçelik, B. (2016). Functional and nutritional properties of some turkish traditional foods. Functional Properties of Traditional Foods, 12, 87-104. http://dx.doi. org/10.1007/978-1-4899-7662-8_6.

Gül, A., Ozel, R., \& Isik, H. (2005). Adana ili merkezinde tüketicilerin biber salçası tüketimini etkileyen faktörler. Journal of the Faculty of Agriculture of Harran University, 9, 23-31.

Hanif, S. M., Meher, M. M., \& Anower, M. (2016). Field study on efficacy of red pepper (capsicum annum) along with antibiotics against newcastle disease in broiler at Narail Sadar Upazilla, Bangladesh. Wayamba Journal of Animal Science, 8, 1460-1466.

Kilic, O., Gündüz, O., Aydin, G., \& Alkan, I. (2011). Determination of consumer behaviour in tomato and pepper paste consumption: a case study from Samsun Province, Turkey. International Journal of Social and Economic Sciences, 1, 119-123.

Kim, J. E., Choi, H. S., Lee, D. U., \& Min, S. C. (2017a). Effects of processing parameters on the inactivation of Bacillus cereus spores on red pepper (Capsicum annum L.) flakes by microwave-combined cold plasma treatment. International Journal of Food Microbiology, 263, 61-66. PMid:29031105. http://dx.doi.org/10.1016/j.ijfoodmicro.2017.09.014.

Kim, M., Go, J., Kim, H., \& Chung, S. (2017b). Understanding the sensory characteristics and drivers of liking for gochujang (Korean fermented chili pepper paste). Food Science and Biotechnology, 26(2), 409-418. http://dx.doi.org/10.1007/s10068-017-0056-8.
Kim, S. H., Kim, M. S., Lee, M. S., Park, Y. S., Lee, H. J., Kang, S., Lee, H. S., Lee, K.-E., Yang, H. J., Kim, M. J., Lee, Y.-E., \& Kwon, D. Y. (2016). Korean diet: characteristics and historical background. Journal of Ethnic Foods, 3(2), 26-31. http://dx.doi.org/10.1016/j. jef.2016.03.002.

Kuleaşan, H., \& Okur, M. (2012). Industrial production of traditional red pepper paste and prevention of spoilage during storage. Journal of Food Agriculture and Environment, 10(2), 241-246.

Li, Z., Dong, L., Huang, Q., \& Wang, X. (2016). Bacterial communities and volatile compounds in Doubanjiang, a Chinese traditional red pepper paste. Journal of Applied Microbiology, 120(6), 1585-1594. PMid:26973023. http://dx.doi.org/10.1111/jam.13130.

Lim, J., Park, E. S., Cheigh, H. S., \& Lee, D. S. (2001). Effect of packaging unit and temperature on the volume expansion of flexible permeable package of kimchi. Packaging Technology \& Science, 14(2), 41-48. http://dx.doi.org/10.1002/pts.536.

Nath, P., Kale, S. J., Chauhan, O. P., \& Gupta, R. K. (2016). High pressure processing induced changes in bioactive compounds, antioxidant activity, microbial safety and color attributes of coriander paste. Agricultural Research, 5(2), 182-192. http://dx.doi.org/10.1007/ s40003-015-0200-8.

Riquelme, N., \& Matiacevich, S. (2017). Characterization and evaluation of some properties of oleoresin from Capsicum annuum var. cacho de cabra. CYTA: Journal of Food, 15(3), 344-351. http://dx.doi.org /10.1080/19476337.2016.1256913.

Sanyaolu, A. A. (2016). Postharvest fungal deterioration of tomato (Lycopersicum esculentum mill) and pepper (Capsicum annum L.): the "ESA" connection. The Scientific World Journal, 11(3), 1-10.

Semenli, T., \& Mavi, K. (2010). Determining the yield and several quality parameters of 'Chili Jalapeno' in comparison to 'Pical' and 'Geyik Boynuzu' pepper cultivars under Mediterranean conditions. African Journal of Agricultural Research, 5, 2825-2828.

SPSS Inc. (2010). SPSS for Windows, Version 11.0.1. Chicago: SPSS Inc.

Srinivasan, K. (2016). Biological Activities of Red Pepper (Capsicum annuum) and Its Pungent Principle Capsaicin: A Review. Critical Reviews in Food Science and Nutrition, 56(9), 1488-1500. PMid:25675368. http://dx.doi.org/10.1080/10408398.2013.772090.

Stamp, C. A., \& Labuza, T. P. (2006). Kinetics of the Maillard Reaction between Aspartame and Glucose in Solution at High Temperatures. Journal of Food Science, 48(2), 543-544. http://dx.doi. org/10.1111/j.1365-2621.1983.tb10785.x.

Stat-Ease. (2005). Stat-Ease Design Expert Package, Version 7.0.0. Minneapolis: Stat-Ease.

Tzortzakis, N., \& Chrysargyris, A. (2017). Postharvest ozone application for the preservation of fruits and vegetables. Journal of Food Reviews International, 33(3), 270-315. http://dx.doi.org/10.1080/87559129 .2016 .1175015 .

Wang, J., Fang, X. M., Mujumdar, A. S., Qian, J. Y., Zhang, Q., Yang, X. H., Liu, Y.-H., Gao, Z.-J., \& Xiao, H.-W. (2017). Effect of high-humidity hot air impingement blanching (HHAIB) on drying and quality of red pepper (Capsicum annuum L.). Food Chemistry, 220, 145-152. PMid:27855882. http://dx.doi.org/10.1016/j.foodchem.2016.09.200. 